\title{
SKEMATA DALAM WACANA BERITA KASUS PLAGIARISME REKTOR UNNES DI SURAT KABAR SOLOPOS DAN SUARA MERDEKA
}

\author{
(Schemata in Rector of Unnes's Plagiarism Case News Discourse \\ in Solopos and Suara Merdeka Newspaper)
}

\author{
Endro Nugroho Wasono Aji \\ Balai Bahasa Provinsi Jawa Tengah \\ Jalan Elang Raya 1, Mangunharjo, Tembalang, Semarang, Jawa Tengah \\ Posel:wasonoajie@gmail.com
}

(Naskah Diterima 12 Oktober 2020-Direvisi 14 Desember 2020_-Disetujui 14 Desember 2020)

\begin{abstract}
The mass media sometimes write different stories to describe the same event. This happened in the case of the Unnes Rector's plagiarism. In this case, the newspaper Solopos made different news from the Suara Merdeka newspaper. This article will discuss the news discourse schemes published in both newspapers. Schemata are structures or elements of discourse that are arranged in a complete text. From this scheme, it can be seen the attitudes or views of the newspaper through the arguments it compiles. Descriptive method was used to study the news discourse schema of the two newspapers. Descriptive method is used to explain the language phenomena contained in the news discourse. The results of the study of the discourse schema of news on plagiarism cases in the newspapers Solopos and Suara Merdeka show different things. It can be seen from the title, lead, and content of the news. In its news content, the Solopos newspaper contains news from two parties, namely from the DK of UGM and the Rector of Unnes, but the portions are not balanced. On the other hand, from the headline and content of Suara Merdeka, the view is that the Rector of Unnes is not proven to have committed plagiarism. Suara Merdeka newspaper contains news from one side only, the Rector of Unnes.
\end{abstract}

Keywords: reality, schemata, discourse

\begin{abstract}
Abstrak
Media massa kadang menulis berita yang berbeda untuk menggambarkan peristiwa yang sama. Hal tersebut terjadi pada kasus plagiarisme Rektor Unnes. Pada kasus tersebut surat kabar Solopos membuat berita yang berbeda dengan surat kabar Suara Merdeka. Artikel ini akan membahas skemata wacana berita yang dimuat di kedua surat kabar tersebut. Skemata merupakan struktur atau elemen wacana yang disusun dalam sebuah teks yang utuh. Dari skemata tersebut dapat diketahui sikap atau pandangan surat kabar melalui argumen yang disusunnya. Untuk mengkaji skemata wacana berita kedua surat kabar tersebut digunakan metode deskriptif. Metode deskriptif digunakan untuk menjelaskan fenomena bahasa yang terdapat di dalam wacana berita tersebut. Hasil dari kajian skemata wacana berita kasus plagiarisme di surat kabar SOLOPOS dan Suara Merdeka menunjukkan hal yang berbeda. Dilihat dari judul, teras, dan isi berita SOLOPOS berpandangan bahwa dalam kasus tersebut Rektor Unnes terbukti melakukan plagiasi. Dalam isi beritanya surat kabar SOLOPOS memuat berita dari dua pihak, yaitu dari sisi DK UGM dan dari sisi Rektor Unnes, tetapi porsinya tidak berimbang. Sebaliknya, dilihat dari judul dan isi berita Suara Merdeka berpandangan bahwa Rektor Unnes tidak terbukti melakukan plagiasi. Surat kabar Suara Merdeka memuat berita dari satu sisi saja, yaitu pihak Rektor Unnes.
\end{abstract}

Kata Kunci: realitas, skemata, wacana 


\section{PENDAHULUAN}

Informasi atau berita yang disampaikan ke khalayak sering kali berbeda antara media yang satu dan yang lainnya. Hal tersebut terjadi karena wartawan atau penulis berita ketika melaporkan sebuah peristiwa atau realitas dipengaruhi oleh banyak hal. Menurut pandangan konstruksionis, berita yang dimuat media massa melalui sebuah proses. Proses tersebut berupa konstruksi dari fakta oleh wartawan atau penulis berita yang bersifat subjektif. Realitas tersebut muncul karena dihadirkan oleh konsep subjektif wartawan. Realitas tercipta lewat sebuah konstruksi yang berasal dari sudut pandang tertentu dari wartawan. Di sini tidak ada realitas yang bersifat objektif karena tercipta melalui konstruksi dan pandangan tertentu. Oleh karena itu, realitas dapat berbeda-beda bergantung pada bagaimana konsepsi ketika realitas itu dipahami oleh pembuat berita yang mempunyai pandangan yang berbeda-beda (Eriyanto, 2002:22). Dengan demikian, etika, pilihan moral, dan keberpihakan wartawan adalah bagian yang integral dalam produksi berita.

Dalam konstruksi realitas, proses dimulai dengan adanya realitas pertama yang berupa keadaan, benda, pikiran, orang, atau peristiwa, atau yang lainnya. Realitas pertama inilah yang dikonstruksikan oleh pelaku konstruksi (wartawan). Dalam membuat wacana ini pelaku konstruksi dipengaruhi oleh pelbagai faktor. Secara umum sistem komunikasi adalah faktor yang memengaruhi sang pelaku dalam membuat wacana (berita). Dalam sistem komunikasi yang bebas, wacana yang terbentuk akan berbeda dari wacana sistem komunikasi yang dibatasi. Secara lebih khusus, dinamika internal dan eksternal pelaku konstruksi memengaruhi wacana yang terbentuk. Di satu sisi, hal ini menunjukkan bahwa pembentukan wacana tidak dalam ruang vakum, di sisi lain pelaku konstruksi sendiri bukanlah orang yang sepenuhnya mampu mengendalikan realitas (Hamad, 2010:37).

Perbedaan konstruksi realitas inilah yang mengakibatkan perbedaan sudut pandang media dalam menyampaikan berita. Hal inilah yang terjadi ketika harian Suara Merdeka dan Solopos memberitakan kasus plagiarisme Rektor Unnes. Meskipun keduanya memberitakan realitas yang sama, cara pemberitaan keduanya berbeda. Harian Solopos dalam pemberitaan kasus tersebut pada tanggal 15 Juli 2020 mengambil judul "DK UGM Minta Cabut Gelar Rektor Unnes". Sementara itu, sehari setelahnya, 16 Juli 2020, harian Suara Merdeka pada kasus yang sama menyajikan berita dengan judul "Plagiasi Rektor Unnes Tidak Terbukti". Untuk membahas hal tersebut, artikel ini akan mengkaji bagaimana skemata wacana kasus plagiarisme Rektor Unnes dari harian Solopos dan Suara Merdeka sehingga memunculkan dua pemberitaan yang berbeda. Artikel ini hanya membahas sebatas bagaimana struktur teks (skemata) membentuk wacana kedua pemberitaan tersebut. Substansi isi berita tidak menjadi pembahasan utama dari kajian ini karena untuk menguji kebenaran isi berita perlu penelitian yang lebih rumit dan mendalam.

Kajian dengan menggunakan skemata sebagai alat analisis telah beberapa dilakukan, antara lain oleh Rahmanadia yang berjudul "Analisis Penggunaan Skemata dalam Bahasa Iklan Anak" yang dimuat di Ranah (Rahmanadia, 2012) dan Wasono Aji yang berjudul "Skemata dalam Wacana Advertorial Madu Bima 99 di Harian Radar Tegal" yang dimuat di Prosiding Hasil Penelitian Kebahasaan dan Kesastraan Balai Bahasa Jawa Tengah (Wasono Aji, 2018).

Rahmanadia (2012) membahas wacana bahasa iklan menggunakan teori skemata yang berhubungan dengan struktur kognitif yang ada di dalam pikiran seseorang. Penelitian tersebut membahas penggunaan bahasa dengan memanfaatkan 
skemata dalam pembuatan iklan anak. Iklan anak yang efektif dan efisien dapat memancing pengalaman yang dimiliki oleh seorang anak ketika membaca iklan tersebut sehingga anak tersebut akan lebih mudah mengingat pesan yang disampaikan. Adapun Wasono Aji (2018) membahas bagaimana bahasa digunakan individu atau institusi untuk memengaruhi atau mendominasi khalayak. Data yang digunakan dalam artikel tersebut adalah wacana iklan dalam advertorial di harian Radar Tegal. Adapun pisau yang digunakan untuk mengkaji adalah analisis wacana kritis model Norman Fairclough. Berdasarkan skemata yang dikaitkan dengan praktik diskursif dan sosiokultural disimpulkan bahwa wacana advertorial di harian Radar Tegal memarjinalkan dokter (obat medis) melalui testimoni sosok yang ditampilkan dalam wacana tersebut untuk kepentingan promosi produknya.

Rahmanadia (2012) dan Wasono Aji (2018) sama-sama menggunakan skemata, tetapi pemanfaatannya berbeda. Artikel ini mengkaji bagaimana skemata dalam membentuk sebuah wacana berita yang berbeda, padahal realitas yang disampaikan sama. Sementara itu, wacana yang dikaji Rahmanadi (2012) dan Wasono Aji (2018) benar-benar wacana yang berbeda realitasnya antara wacana satu dan wacana lainnya. Selain itu, objek kajian yang dibahas pun berbeda, yaitu wacana berita di koran atau surat kabar.

Skemata yang dimaksud dalam kajian ini adalah bagaimana struktur atau elemen wacana disusun dalam sebuah teks yang utuh (Kasemin, 2003:195). Salah satu bentuk yang penting dalam skema teks adalah argumentasi (van Dijk, 2001:310). Dari skema ini dapat diketahui bagaimana argumentasi disusun dalam sebuah wacana. Pendapat serupa disampaikan oleh Fairclough (Fairclough, 2003:177) yang mendefinisikan skema (bentuk jamak skemata) sebagai gambaran mental struktur tekstual yang berskala luas. Sebuah teks menurut Fairclough (Fairclough, 2003:155) memiliki struktur yang mungkin dibuat dari elemen yang dapat diperkirakan dalam sebuah tatanan yang dapat diprediksikan.

Teks berita koran atau surat kabar mempunyai bentuk dan skema tertentu yang umumnya terdiri atas dua kategori skema besar, yaitu summary (ringkasan) dan story (cerita). Summary umumnya ditandai oleh dua elemen, yaitu judul dan lead (teras). Judul dan teras berita merupakan elemen yang paling penting dalam pemberitaan karena elemen skema ini menunjukkan tema yang ingin ditampilkan oleh penulis berita. Lead umumnya berfungsi sebagai pengantar sebelum masuk ke dalam isi berita selengkapnya. Sementara itu, story adalah isi berita secara keseluruhan. Isi berita secara hipotetis mempunyai dua subkategori, yaitu situasi dan komentar (Eriyanto, 2001:232). Struktur wacana berita surat kabar biasanya disusun dengan gaya piramida terbalik. Urutan elemenelemen berita disusun dari yang paling penting diikuti elemen-elemen berikutnya yang semakin kurang penting. Tujuannya memudahkan pembaca agar dapat mengetahui isi berita lebih cepat (Badara, 2012:23; Wibowo, 2001:46).

Dalam sebuah wacana berita surat kabar, sering kali peristiwa tidak disusun secara kronologis (struktur teksnya). Elemen-elemen yang diharapkan oleh pembaca belum tentu muncul dalam teks. Urutan elemen yang muncul tidak selalu logis. Ada bagian yang sengaja tidak dihadirkan dalam teks. Tentu ada alasan mengapa perancang teks menata teks sedemikian rupa. Untuk tujuan tertentu, penghasil teks akan mengurutkan sesuai dengan "selera" penghasil teks, bukan menyesuaikan "harapan" konsumen teks (Darma, 2009:78; Santosa, 2012:164). Dengan demikian, skemata sebuah wacana merupakan cerminan sikap atau pandangan si pembuat teks. Hal inilah yang akan dibahas lebih lanjut dalam artikel ini. Bagaimana skemata wacana berita disusun oleh surat kabar Solopos dan Suara Merdeka sehingga menampilkan berita 
yang berbeda, tetapi mengacu pada realitas yang sama.

\section{METODE PENELITIAN}

Data dalam kajian ini diambil dari wacana pemberitaan kasus plagiasi Rektor Unnes yang dimuat di harian Solopos dan Suara Merdeka. Surat kabar Solopos memuat berita tersebut pada tanggal 15 Juli 2020 dengan judul "DK UGM Minta Cabut Gelar Rektor Unnes". Sementara itu, harian Suara Merdeka sehari setelahnya, 16 Juli 2020, menyajikan berita dengan judul "Plagiasi Rektor Unnes Tidak Terbukti”.

Pengumpulan data dalam kajian ini menggunakan teknik pustaka, yaitu menggunakan sumber-sumber tertulis untuk memperoleh data (Soebroto, 2007:47). Sumber-sumber tertulis berwujud surat kabar. Di dalam surat kabar tersebut terdapat beragam artikel. Adapun artikel yang diambil sebagai data adalah artikel berita. Penggunaan bahasa yang disimak berupa wacana pemberitaan plagiasi Rektor Unnes. Wacana tersebut dicermati kemudian diseleksi dan diklasifikasi berdasarkan struktur teks yang terdapat dalam wacana.

Untuk menganalisis data digunakan metode deskriptif. Metode deskriptif adalah suatu metode yang digunakan untuk menjelaskan fakta atau fenomena yang ada tanpa mempertimbangkan benar salahnya penggunaan bahasa (Sudaryanto, 1988:62).

\section{PEMBAHASAN}

Wacana berita umumnya menggunakan gaya piramida terbalik. Struktur wacana disusun dari elemen yang paling penting ke elemen yang kurang penting. Pemilihan urutan elemen-elemen yang ada dalam wacana mencerminkan sikap atau pandangan surat kabar terhadap sebuah realitas. Keberpihakan surat kabar yang direpresentasi oleh penulis berita terlihat dari rangkaian peristiwa yang tersusun menjadi sebuah wacana yang utuh. Sikap surat kabar terhadap realitas tercermin dari bagaimana penulis berita merekonstruksi realitas tersebut, bagaimana wartawan menyusun argumen. Dengan kata lain, dari skemata sebuah wacana dapat dilihat sikap atau pandangan pemberitaan dari sebuah surat kabar. Untuk mengetahui sikap atau pandangan surat kabar Solopos dan Suara Merdeka terhadap pemberitaan kasus plagiarisme Rektor Unnes masing-masing dianalisis bagaimana skemata wacana berita yang ditampilkan oleh kedua surat kabar tersebut.

\section{Skemata Pemberitaan Wacana Kasus Plagiasi Rektor Unnes di Harian Solopos}

Skemata wacana berita surat kabar dapat dibedakan menjadi judul, lead atau teras, dan isi berita. Dari skemata wacana berita tersebut terlihat sikap atau pandangan surat kabar yang bersangkutan. Berikut ini dibahas skemata wacana berita dari judul berita, teras, dan isi berita yang dimuat harian Solopos.

\section{Analisis Wacana pada Judul Berita}

Judul berita merupakan bagian penting dari berita. Judul biasanya mencerminkan isi berita. Judul merupakan summary atau ringkasan dari berita tersebut. Oleh karena itu, judul sering kali mencerminkan sikap atau pandangan bahkan ideologi sebuah surat kabar. Surat kabar Solopos dalam kasus plagiarisme Rektor Unnes memuat berita dengan judul sebagai berikut.

\section{"DK UGM Minta Cabut Gelar Doktor Rektor Unnes"}

Berita tersebut termuat di halaman berita utama di halaman 3. Pemilihan judul yang digunakan oleh surat kabar Solopos mengindikasikan sikap atau pandangan dari redaksi bahwa Rektor Unnes dalam kasus plagiarisme tersebut bersalah. Secara implisit hal tersebut tampak ungkapan minta cabut gelar doktor. Dengan 
pemintaan pencabutan gelar Rektor Unnes menunjukkan bahwa rektor tersebut telah terbukti melakukan plagiasi sehingga DK UGM meminta gelar doktor Rektor Unnes dicabut. Yang menarik di sini adalah penggunaan ungkapan tidak langsung pada judul berita. Padahal, bisa saja digunakan judul yang menggunakan ungkapan langsung, misalnya "Plagiasi Rektor Unnes Terbukti" atau "Rektor Unnes Plagiat". Ungkapan tidak langsung digunakan sebagai judul berita kemungkinan sebagai hedging (pengelakan). Jadi, misalnya, berita itu ternyata tidak benar (plagiasi Rektor Unnes tidak terbukti) pihak Solopos dapat mengelak dengan mengatakan bahwa itu adalah pernyataan dari DK UGM. Pandangan dari redaksi Solopos bahwa Rektor Unnes dalam kasus plagiarisme tersebut bersalah diperkuat oleh teras berita seperti dalam penjelasan subbab berikut.

\section{Analisis Wacana pada Teras Berita}

Selain judul, bagian dari berita yang tidak kalah penting adalah teras atau lead. Teras berita yang dimuat Solopos menguatkan sikap redaksi surat kabar tersebut.

SEMARANG-Dewan Kehormatan Universitas Gadjah Mada Yogyakarta merekomendasikan gelar doktor Rektor Universitas Negeri Semarang (Unnes), Fathur Rokhman, dicabut.

- Dewan Kehormatan UGM menemukan bukti dugaan plagiarism Fathur Rokhman dalam disertasi.

- Rekomendasi itu tidak dijalankan oleh Rektor UGM

Teras berita tersebut terdiri atas tiga elemen informasi. Ketiga informasi yang disampaikan oleh surat kabar Solopos, yaitu Dewan Kehormatan

UGM merekomendasikan pencabutan gelar doktor Rektor Unnes, Dewan Kehormatan UGM menemukan bukti dugaan plagiarisme, dan rekomendasi tersebut tidak dijalankan oleh Rektor UGM. Ketiga elemen pada teras berita Solopos tersebut mendukung judul berita. Dengan demikian, dilihat dari judul dan teras berita jelas sekali pandangan surat kabar Solopos bahwa Rektor Unnes terbukti melakukan plagiarisme.

\section{Analisis Wacana pada Isi Berita}

Wacana isi berita berdasarkan isinya dapat dibagi menjadi beberapa elemen. Dari elemen-elemen tersebut akan tampak cara berpikir atau argumen yang dibuat oleh penulis berita. Dalam wacana isi berita surat kabar Solopos yang berjudul "DK UGM Minta Cabut Gelar Doktor Rektor Unnes" berdasarkan skemanya dapat dibagi menjadi dua elemen. Elemen yang pertama terdiri atas beberapa paragraf yang membahas bukti plagiarisme yang dilakukan oleh Rektor Unnes.

Skema argumen wacana isi berita (elemen pertama) surat kabar Solopos dapat disusun sebagai berikut.

\begin{tabular}{|c|c|}
\hline Argumen & \\
\hline Argumen 1 & $\begin{array}{l}\text { DK UGM mengeluarkan } \\
\text { rekomendasi berdasarkan } \\
\text { bukti-bukti yang } \\
\text { ditemukan. }\end{array}$ \\
\hline Argumen 2 & $\begin{array}{l}\text { Isi dokumen rekomendasi } \\
\text { dan bukti-bukti } \\
\text { pelanggaran yang } \\
\text { dilakukan oleh Rektor } \\
\text { Unnes berdasarkan } \\
\text { temuan DK UGM. }\end{array}$ \\
\hline Argumen 3 & $\begin{array}{lr}\text { Menurut DK UGM Fatur } \\
\text { Rokhman } & \text { dalam } \\
\text { memberikan keterangan } \\
\text { berbelit-belit } \\
\text { melontarkan dan } \\
\text { bernada ancaman. }\end{array}$ \\
\hline Argumen 4 & $\begin{array}{lr}\text { Rekomendasi } & \text { telah } \\
\text { diserahkan kepada } & \text { Rektor UGM, tetapi tidak } \\
\text { Reranan oleh Rektor } & \text { Rigunakan } \\
\text { UGM untuk memberikan } \\
\text { sanksi kepada Fatur } \\
\text { Rokhman. }\end{array}$ \\
\hline
\end{tabular}




\begin{tabular}{|c|c|}
\hline Argumen 5 & $\begin{array}{lr}\text { Ketua DK UGM tidak } \\
\text { merespons } & \text { ketika } \\
\text { dihubungi } & \text { oleh } \\
\text { SOLOPOS. } & \\
\end{array}$ \\
\hline Simpulan & $\begin{array}{l}\text { SOLOPOS memuat berita } \\
\text { berdasarkan pendapat } \\
\text { DK UGM bahwa Rektor } \\
\text { Unnes terbukti } \\
\text { melakukan plagiarisme, } \\
\text { tetapi verifikasi dengan } \\
\text { Ketua DK UGM tidak } \\
\text { direspons. }\end{array}$ \\
\hline
\end{tabular}

Berdasarkan skema di atas isi berita surat kabar Solopos terdiri atas beberapa elemen yang memberi informasi tentang DK UGM yang mengeluarkan rekomendasi berdasarkan bukti-bukti yang ditemukan: isi dokumen rekomendasi dan bukti-bukti pelanggaran yang dilakukan oleh Rektor Unnes berdasarkan temuan DK UGM; menurut DK UGM, Fatur Rokhman dalam memberikan keterangan berbelit-belit dan melontarkan kalimat bernada ancaman; rekomendasi telah diserahkan kepada Rektor UGM, tetapi tidak digunakan oleh Rektor UGM untuk memberikan sanksi kepada Fatur Rokhman; dan elemen terakhir menyatakan Ketua DK UGM tidak merespons ketika dihubungi oleh Solopos. Elemen terakhir pada isi berita tersebut seharusnya tidak ada (tidak ditulis) karena informasi yang diberikan seolah-olah mementahkan argumen yang disusun sebelumnya. Dalam hal ini penulis berita mengangkat berita berdasarkan informasi dari DK UGM, tetapi tidak melakukan verifikasi terhadap kebenaran informasi tersebut. Hal tersebut terlihat pada pernyataan "Ketua DK UGM tidak merespons ketika dihubungi oleh SOLOPOS". Khalayak pembaca tentu akan mempertanyakan dari mana Solopos mendapat informasi yang dikeluarkan oleh DK UGM? Yang kedua, mengapa Ketua DK UGM tidak merespons konfirmasi dari pihak Solopos? Pertanyaan selanjutnya, ada apa antara DK UGM dan Rektor UGM sehingga rekomendasi DK UGM tidak dilaksanakan oleh Rektor UGM. Sebaliknya, Rektor UGM malah mengeluarkan surat keputusan yang menyatakan bahwa Fatur Rokhman tidak terbukti melakukan plagiasi. Hal ini terlihat dari elemen kedua isi berita surat kabar Solopos.

Elemen kedua dari isi berita berupa pandangan dari pihak Rektor Unnes. Menurut Fatur Rokhman kasus dugaan plagiarisme terhadap dirinya sudah selesai karena berdasarkan hasil pemeriksaan Dewan Kehormatan UGM dan Keputusan Rektor UGM dirinya dinyatakan bukan plagiat, seperti tampak pada kutipan isi berita berikut.

Sementara itu, Fathur Rokhman menyatakan kasus dugaan plagiarisme terhadap dirinya telah selesai. Hal itu menyusul keputusan Rektor UGM pada 2 April 2020, yang menyatakan dirinya tidak plagiat.

"Keputusan itu menyatakan berdasarkan hasil pemeriksan DKU [Dewan Kehormatan UGM], pendapat hukum dari beberapa ahli dinyatakan bahwa dugaan plagiarisme dalam disertasi Fathur Rokhman 2003 atas skripsi Ristin Setiyani dan Nefi Yustiani tidak terbukti. Jadi masalahnya sudah selesai," ujar Fathur Rokhman.

Dilihat dari skematanya berita surat kabar Solopos berdasarkan judul, lead, dan sebagian besar isi berita menginformasikan bahwa Rektor Unnes, Fatur Rokhman, terbukti melakukan plagiarisme berdasarkan rekomendasi Dewan Kehormatan UGM. Namun, pada bagian akhir isi berita surat kabar Solopos memberitakan informasi yang sebaliknya, yaitu Rektor Unnes tidak terbukti melakukan plagiasi. Hal ini menunjukkan bahwa surat kabar Solopos melakukan reportase dari dua belah pihak (cover both sides), yaitu dari pihak DK UGM dan pihak Rektor Unnes. Namun, pemberitaannya tidak berimbang. Informasi dari pihak Rektor Unnes hanya mendapatkan porsi yang sangat sedikit (bagian dari isi berita 
dan ditempatkan pada dua paragraf terakhir). Sementara itu, pemberitaan dari pihak DK UGM (yang tidak terverifikasi) mendapat porsi yang sangat banyak, yaitu bagian judul, lead, dan sebagian besar isi berita. Hal tersebut menunjukkan keberpihakan surat kabar Solopos pada pihak DK UGM.

\section{Skemata Pemberitaan Wacana Kasus Plagiasi Rektor Unnes di Harian Suara Merdeka}

Skemata wacana berita surat kabar Suara Merdeka sedikit berbeda dengan surat kabar Solopos. Skemata dalam berita Suara Merdeka hanya terdiri atas judul dan isi berita, tidak ada lead atau teras berita. Berikut ini pembahasan skemata pemberitaan kasus plagiarisme Rektor Unnes di surat kabar Suara Merdeka.

\section{Analisis Wacana pada Judul Berita}

Surat kabar Suara Merdeka dalam kasus plagiarisme Rektor Unnes memuat berita dengan judul sebagai berikut.

\section{"Plagiasi Rektor Unnes Tidak Terbukti"}

Berita tersebut termuat di halaman berita nasional di halaman 2. Kebalikan dari surat kabar Solopos, redaksi Suara Merdeka mengambil judul "Plagiasi Rektor Unnes tidak Terbukti". Hal tersebut menunjukkan bahwa surat kabar Suara Merdeka berpihak pada Rektor Unnes dengan menyatakan bahwa Rektor Unnes tidak melakukan plagiarisme. Dengan kata lain, dalam kasus plagiarisme tersebut Rektor Unnes tidak bersalah.

\section{Analisis Wacana pada Teras Berita}

Tidak semua berita yang dimuat di surat kabar Suara Merdeka terdapat teras atau lead. Dalam satu lembar halaman koran hanya ada satu atau dua berita yang menyertakan lead. Berita yang ada lead-nya biasanya adalah berita utama. Hal itu tampak dari posisi berita dan judul berita yang lebih menonjol karena dicetak lebih besar dan lebih tebal dari berita lainnya di dalam lembar halaman tersebut. Teras dalam wacana berita kasus plagiarism Rektor Unnes di harian Suara Merdeka tidak ada.

\section{Analisis Wacana pada Isi Berita}

Skema isi berita Koran Suara Merdeka terdiri atas beberapa elemen yang mendukung pernyataan judul berita. Skema argumen wacana isi berita surat kabar Suara Merdeka dapat disusun sebagai berikut.

\section{Argumen}

\begin{tabular}{|c|c|}
\hline Argumen 1 & $\begin{array}{lrr}\text { Menurut } & \text { Muhtar } & \text { Hadi } \\
\text { Wibowo } & \text { (kuasa hukum) } \\
\text { Rektor } & \text { Unnes tidak } \\
\text { terbukti } & \text { melakukan } \\
\text { plagiasi. } & & \end{array}$ \\
\hline Argumen 2 & $\begin{array}{l}\text { Muhtar Hadi Wibowo } \\
\text { menyebut Prof Fathur } \\
\text { sangat kooperatif saat } \\
\text { dilakukan pemeriksaan } \\
\text { oleh DKU (Dewan } \\
\text { Kehormatan Universitas) } \\
\text { UGM. }\end{array}$ \\
\hline Argumen 3 & $\begin{array}{l}\text { Menurut Muhtar tuduhan } \\
\text { plagiasi merupakan } \\
\text { kezaliman yang disengaja } \\
\text { oleh pihak yang ingin } \\
\text { menjatuhkan Prof Fathur. } \\
\text { Dia beralasan, tuduhan itu } \\
\text { berulang dan pola-pola } \\
\text { tuduhan tersebut } \\
\text { mengindikasikan adanya } \\
\text { motif politik yang kuat di } \\
\text { belakangnya. }\end{array}$ \\
\hline Argumen 4 & $\begin{array}{l}\text { Kepala UPT } \\
\text { Unnes, Humas } \\
\text { Burhanuddin, S.S., M.A. } \\
\text { menambahkan } \\
\text { tuduhan plagiasi } \\
\text { menimbulkan } \\
\text { kesalahpahaman }\end{array}$ \\
\hline
\end{tabular}




\begin{tabular}{ll}
\hline & \multicolumn{2}{l}{ bahkan kebencian terhadap } \\
& individu dan lembaga. \\
\hline Simpulan & Tuduhan plagiasi tidak \\
& terbukti, ada motif politik, \\
& dan menyebabkan \\
& kebencian terhadap \\
& individu dan lembaga. \\
\hline
\end{tabular}

Berbeda dengan surat kabar Solopos, Suara Merdeka mengambil berita dari satu sisi, yaitu pihak Rektor Unnes yang direpresentasi oleh kuasa hukumnya, yaitu Muhtar Hadi Wibowo dan Kepala UPT Humas Unnes, Muhamad Burhanuddin, S.S., M.A. Oleh karena itu, tidak mengherankan jika informasi yang disampaikan memberikan gambaran yang positif terhadap Rektor Unnes, seperti tidak terbukti melakukan plagiasi dan bersikap sangat kooperatif. Bahkan, dalam kasus ini Rektor Unnes digambarkan sebagai korban kezaliman pihak tertentu. Jadi, posisi subjek Rektor Unnes direpresentasikan sebagai pihak yang dimarjinalkan oleh pihak-pihak yang ingin menjatuhkan Fatur Rokhman. Walaupun tidak dijelaskan secara jelas siapa pihak-pihak tersebut. Hal tersebut menunjukkan keberpihakan surat kabar Suara Merdeka pada pihak Rektor Unnes.

\section{PENUTUP}

Berdasarkan pembahasan skemata dalam wacana kasus plagiarisme Rektor Unnes di atas dapat disimpulkan bahwa surat kabar Solopos berpandangan Rektor Unnes terbukti melakukan plagiasi. Hal tersebut tampak pada bagian judul, teras, dan isi berita. Pada wacana berita di surat kabar Solopos ada dua pihak yang menjadi sumber berita, yaitu Dewan Kehormatan Universitas Gadjah Mada (DK UGM) dan Fatur Rokhman (Rektor Unnes). Namun, dalam pemberitaan porsinya tidak berimbang. Hal tersebut menunjukkan keberpihakan surat kabar Solopos pada pihak DK UGM. Sebaliknya, skemata wacana berita di surat kabar Suara Merdeka berpandangan bahwa Rektor Unnes tidak terbukti melakukan plagiasi. Sumber berita yang diambil oleh surat kabar Suara Merdeka dalam pemberitaannya hanya dari satu sisi, yaitu dari pihak Rektor Unnes. Hal tersebut menunjukkan keberpihakan surat kabar Suara Merdeka pada pihak Rektor Unnes.

\section{DAFTAR PUSTAKA}

Badara, A. (2012). Analisis Wacana: Teori, Metode, dan Penerapannya pada Wacana Media. Jakarta: Kencana Prenada Media.

Darma, Y. A. (2009). Analisis Wacana Kritis. Bandung: Yrama Widya.

Eriyanto. (2001). Analisis Wacana: Pengantar Analisis Teks Media. Yogyakarta: LKiS.

Eriyanto. (2002). Analisis Framing Konstruksi, Ideologi, dan Politik Media. Yogyakarta: LKiS.

Fairclough, N. (2003). Language and Power: Relasi Bahasa, Kekuasaan dan Ideologi. Malang: Boyan.

Hamad, I. (2010). Komunikasi sebagai Wacana. Jakarta: La Tofi Enterprise.

Kasemin, K. (2003). Mendamaikan Sejarah: Analisis Wacana Pencabutan TAP MPRS/XXV/1966. Yogyakarta: LKiS.

Rahmanadia, H. (2012). Analisis Penggunaan Skemata dalam Bahasa Iklan Anak. Ranah, 1(1), 10-20.

Santosa, A. (2012). Studi Bahasa Kritis Menguak Bahasa Membongkar Kuasa. Bandung: Mandar Maju.

Soebroto, E. (2007). Pengantar Metode Penelitian Linguistik Struktural. Surakarta: UNS Press.

Sudaryanto. (1988). Metode Linguistik. Yogyakarta: Gadjah Mada University Press.

van Dijk, T. A. (2001). Principles of Critical Discourse Analysis. In Discourse Theory and Practice. London: Sage Publications.

Wasono Aji, E. N. (2018). Skemata dalam 
Wacana Advertorial Madu Bima 99 di Harian Radar Tegal. Prosiding Hasil Seminar Kebahasaan Dan Kesastraan, 159-170. Semarang: Balai Bahasa Jawa Tengah.

Wibowo, W. (2001). Manajemen Bahasa. Jakarta: Gramedia. 